\title{
Disturbance alters ecosystem engineering by a canopy-forming alga
}

\author{
JACQUELINE B. POCKLINGTON ${ }^{1,2,3,4}$, STUART R. JENKINS ${ }^{4,5}$, ALECIA BELLGROVE ${ }^{6}$, \\ MICHAEL J. KEOUGH ${ }^{3}$, TIM D. O'HARA ${ }^{1}$, PATRICIA E. MASTERSON-ALGAR ${ }^{4,7}$ \\ AND STEPHEN J. HAWKINS ${ }^{4,8}$
}

${ }^{1}$ Department of Marine Invertebrates, Museum Victoria, Carlton, Victoria 3053, Australia, ${ }^{2}$ Present address: School of Marine Science and Technology, Newcastle University, Dove Marine Laboratory, Cullercoats, Tyne \& Wear NE30 4PZ, UK, ${ }^{3}$ School of BioSciences, University of Melbourne, Victoria 3010, Australia, ${ }^{4}$ The Marine Biological Association of the United Kingdom, Plymouth PL12PB, UK, ${ }^{5}$ School of Ocean Sciences, Bangor University, Menai Bridge, Anglesey LL59 5AB, UK, ${ }^{6}$ Deakin University, School of Life and Environmental Sciences, Centre for Integrative Ecology, Warrnambool Campus, PO Box 423, Warrnambool, Victoria 3280, Australia, ${ }^{7}$ School of Healthcare Sciences, Bangor University, Bangor LL57 2EF, UK, ${ }^{8}$ Present address: Ocean and Earth Science, University of Southampton, National Oceanography Centre Southampton, Waterfront Campus, European Way, Southampton $\mathrm{SO}_{14} 3 \mathrm{ZH}$, UK

\begin{abstract}
Canopy-forming fucoid algae have an important role as ecosystem engineers on rocky intertidal shores, where they increase the abundance of species otherwise limited by exposure during low tide. The facilitative relationship between Ascophyllum nodosum and associated organisms was explored using a frond breakage experiment (100\%, $50 \%, 25 \%$, $0 \%$ intact-frond treatments) in southern England, to assess the consequences of disturbance. Understorey substratum temperature was on average $3^{\circ} \mathrm{C}$ higher in $0 \%$ and $25 \%$ intact-frond treatments than in plots with $50 \%$ and $100 \%$ intact fronds. Light (as PAR during low tide) doubled in o\% intact-frond treatments in comparison to other treatments (which had similar light levels). Mobile invertebrate species richness declined by on average 1 species per $m^{2}$ in the treatments with only $25 \%$ and $0 \%$ intact fronds, and the abundance of Littorina obtusata declined by 2.4-4.2 individuals per $\mathrm{m}^{2}$ in the treatments with 25 and o\% intact fronds. Sessile taxa, including Osmundea pinnatifida and encrusting coralline algae, declined by half on average in the o\% intactfrond treatment. These results suggest that the ability of Ascophyllum to mediate environmental conditions to the understorey is the mechanism responsible for species distributed in the understorey (autogenic ecosystem engineering). The results of this study imply that a pulse disturbance resulting in a 50\% breakage of Ascophyllum fronds significantly increases temperature and decreases the abundance of mobile invertebrates usually associated with Ascophyllum. Sessile taxa associated with Ascophyllum can, however, withstand disturbances down to 25\% intact Ascophyllum fronds.
\end{abstract}

Keywords: Ascophyllum nodosum, community, facilitation, foundation species, macroalgae, marine, intertidal

Submitted 17 August 2016; accepted 20 December 2016; first published online 23 January 2017

\section{INTRDDUCTION}

Canopy-forming algae play important roles in habitat provision and primary production in temperate coastal ecosystems worldwide (Littler \& Murray, 1974; Thompson et al., 2002). They are, however, under threat from a variety of impacts at local and regional scales including eutrophication (Bonsdorff et al., 1997; Rönnberg \& Bonsdorff, 2004), siltation resulting from urbanization (Schiel et al., 2006; Airoldi \& Hawkins, 2007), harvesting (Ang et al., 1996; Zemke-White \& Masao, 1999; Ugarte et al., 2006), trampling (Povey \& Keough, 1991; Keough \& Quinn, 1998; Schiel \& Taylor, 1999; Araújo et al., 2009) and point source pollution (Bellgrove et al., 1997; Keser et al., 2005). Canopy species are being influenced by the overarching effects of climate change interacting with local impacts, including rising and stormier seas (Underwood,

Corresponding author:

J.B. Pocklington

Email: jpocklington@museum.vic.gov.au
1998, 1999; Hawkins et al., 2009) and more frequent extreme high temperatures (Thompson et al., 2002; Keser et al., 2005; Wernberg et al., 2016), perhaps exacerbated by greater grazing pressure (Menge \& Olson, 1990; Davies et al., 2007). Depending on the frequency of recurrence, these perturbations could act as either pulse disturbances (e.g. unusual spike in grazing pressure; Cervin \& Åberg, 1997), or long-term press disturbance (e.g. rising seas). Here we focus on the community consequences of a pulse disturbance that reduced the density of fronds (simulating breakage by herbivory or storm activity) of Ascophyllum nodosum (hereafter referred to as Ascophyllum), the major long-lived, canopy-forming macroalga dominating intertidal shores of the Northern Atlantic (Stephenson \& Stephenson, 1972; Jenkins et al., 2008). Observational (Davies et al., 2007; Gollety et al., 2011) and modelling studies (Hawkins et al., 2009) suggest Ascophyllum is likely to be increasingly disturbed over the coming decades in response to climate change and local anthropogenic impacts.

Individual Ascophyllum plants proliferate vegetatively from long-lived holdfasts, and stands are thought to last for centuries, with individual fronds lasting tens of years, creating a 
perennial habitat for epiphytic and understorey organisms (Araújo et al., 2009). Ascophyllum communities recover slowly after experimental manipulation (Jenkins et al., 2004; Ingólfsson \& Hawkins, 2008) or harvesting (Ang et al., 1996; Zemke-White \& Masao, 1999; Ugarte et al., 2006), taking more than a decade to return to their original state (Ingólfsson \& Hawkins, 2008).

In contrast to previous studies that examined the impacts of complete canopy removal (Bertness \& Leonard, 1997; Petraitis \& Dudgeon, 1999; Jenkins et al., 1999a, b, c, 2004), we were interested in the impacts of partial frond loss, as might result from a pulse disturbance such as overgrazing, or an extreme weather event (e.g. heat wave, storm). The impacts of pulse disturbances resulting in partial canopy loss have been investigated for the fucoids Hormosira banksii (Schiel \& Lilley, 2007) and Fucus gardneri (Speidel et al., 2001), though have not previously been undertaken on Ascophyllum canopies or fronds.

Much attention has been given to press disturbances such as increased temperature due to climate change (Keser et al., 2005; Mieszkowska et al., 2007), increases in grazing pressure (Pavia \& Toth, 2000; Davies et al., 2007) and trampling (Araújo et al., 2009), but a single pulse disturbance in full canopies can have long-term consequences at a local scale (Ingólfsson \& Hawkins, 2008; Wernberg et al., 2016). Whilst full canopies of Ascophyllum can play an autogenic ecosystem engineering (sensu Jones et al., 1994) role, we were interested in assessing the conditions under which this role breaks down, or the threshold frond density beyond which Ascophyllum ceases to be an effective ecosystem engineer. Specifically we tested the following hypotheses: (1) Temperature and light on the substratum will increase in proportion to frond reduction; (2) Changes in community composition will be proportional to frond reduction. Alternatively, (3) there is a threshold density of intact fronds below which Ascophyllum ceases to modulate temperature and light, with community composition showing a similar threshold.

\section{MATERIALS AND METHDDS}

\section{Spatial variation in assemblages associated with Ascophyllum nodosum}

Three sites in southern England were initially surveyed in summer 2006: Batten Bay (Turnchapel) within Plymouth Sound $\left(50^{\circ} 21^{\prime} 27^{\prime \prime} \mathrm{N} 4^{\circ} 07^{\prime} 38^{\prime \prime} \mathrm{W}\right)$, and two sites near the township of Looe $\left(50^{\circ} 20^{\prime} 41^{\prime \prime} \mathrm{N} 4^{\circ} 27^{\prime} 08^{\prime \prime} \mathrm{W}\right)$, hereafter referred to as 'Looe' and 'Hannafore Point'. All sites consisted of gently sloping wave-sheltered sedimentary rock platforms dominated at the mid-shore level by extensive canopies of Ascophyllum, inter-dispersed with patches of Fucus serratus and Fucus vesiculosus.

To assess the spatial variation in assemblages associated with a full canopy of Ascophyllum, all three sites were surveyed. Thirty replicate, haphazardly placed quadrats $(0.3 \times$ $0.3 \mathrm{~m}$, appropriate to the scale of the macrofauna) with $>95 \%$ Ascophyllum canopy cover (naturally lower cover canopies did not occur), were quantitatively sampled at each site for percentage cover of algae and sessile animals (using 49 point-intercepts, see Jenkins et al., 2005) and the abundance of individual mobile macroinvertebrates (defined as those
$>_{5} \mathrm{~mm}$ length), which were counted directly. Where algae and sessile animals occurred in quadrats but not under point-intercepts, they were recorded as present to account for rare species. In contrast to previous work that only examined a limited suite of species (Boaden \& Dring, 1980; Bertness \& Leonard, 1997; Jenkins et al., 1999a, c; Leonard, 1999; Petraitis \& Dudgeon, 1999; Speidel et al., 2001) or took a functional group response (e.g. 'understorey species'; Araújo et al., 2009), a complete inventory of the macrofauna and understorey algae of Ascophyllum stands was made and whole community responses measured (see also Gollety et al., 2011). The percentage covers of algal taxa were recorded as two separate layers: the canopy layer, and the understorey layer, which was revealed by gently moving the canopy aside.

\section{Effects of a pulse disturbance reducing densities of Ascophyllum fronds on the physical environment and associated assemblages}

A manipulative field experiment was conducted to simultaneously test the hypotheses that: (1) temperature and light on the substratum will increase in proportion to frond reduction; (2) changes in community composition will be proportional to frond reduction; or alternatively, (3) there is a threshold density of intact fronds below which Ascophyllum ceases to modulate temperature and light, with community composition showing a similar threshold. Hannafore Point was selected as the best site for experimental manipulation as it had an extensive bed of Ascophyllum, allowing good separation between sample plots, and it was easily accessible during low tide. Twenty haphazardly placed, fixed $4-\mathrm{m}^{2}$ plots were established within a reef area of $\sim 2000 \mathrm{~m}^{2}$, and labelled with plastic tags fixed with stainless steel screws into bedrock. All plots initially had $>95 \%$ Ascophyllum cover and five replicates (all replicates are at the plot level) were assigned randomly to three frond reduction treatments and one unmanipulated control. The Ascophyllum holdfast occurs as a perennial basal disc from which multiple fronds arise directly in a clump, and can regrow after disturbance (Ugarte et al., 2006). The fronds are often very long $(\geq 80 \mathrm{~cm}$ at our sites) and can create different amounts of canopy cover during low tide depending on where they have fallen on the receding tide. Therefore to allow a consistent disturbance to be applied between plots (mimicking frond breakage e.g. due to herbivory or storm activity) the frond density near the holdfast (rather than the percentage canopy cover) was manipulated. In July 2006, fronds in each holdfast clump were trimmed and removed to create the following treatments: $0 \%$ intact fronds (all fronds were removed), $25 \%$ intact fronds ( $75 \%$ of fronds were removed), $50 \%$ intact fronds (50\% of fronds were removed) and $100 \%$ intact fronds (a control with unmanipulated frond densities). It is important to emphasize that the treatments represent the densities of intact fronds relative to the original frond densities and do not necessarily correspond to a linear relationship with canopy percentage cover. For each removal treatment, the fronds were cut at the base with garden secateurs to no more than $10 \mathrm{~cm}$ above the rock surface, to reduce frond density whilst still allowing for vegetative regeneration. Although these short fronds remained in all treatments throughout the experiment, they did not grow above $10 \mathrm{~cm}$ in length and no macroinvertebrates were recorded 
(unpublished data) using it as habitat. Any fronds able to sweep into the treatment plots from outside plants were trimmed back to prevent edge effects.

\section{EFFECTS ON PHYSICAL ENVIRONMENT:}

\section{TEMPERATURE AND LIGHT}

Temperature was recorded on the substratum (under any canopy algae) of each experimental plot using a standard waterproof aquarium thermometer to the nearest $0.1^{\circ} \mathrm{C}$ on all sampling visits. Underwater TidBit Stowaway temperature data loggers (Onset, Bourne, MA, USA) were attached by bolts to the rock in six plots (six loggers unevenly spread over four treatments, $\mathrm{N}=1-2$ due to limited availability) to establish minimum and maximum temperatures within canopy treatments; these were set to record every 10 min over a 3-week period (2.8.2006-23.8.2006, summer). Light was recorded in all plots at sampling visits 7,21 and 36 days as Photosynthetically Active Radiation (PAR) under the canopy (or simply on the substratum in $0 \%$ intact-frond plots) using a LI-COR-250 (LI-COR, Lincoln, NE, USA) meter with a waterproof sensor. All sampling was undertaken during daylight hours at low tide (summer sampling predominantly around midday). Further physical measurements were not taken on other sampling dates due to logistical constraints.

\section{EFFECTS ON ASSOCIATED ASSEMBLAGES: MOBILE}

\section{AND SESSILE MACROINVERTEBRATES AND}

\section{MACROALGAE}

The macroinvertebrate and macroalgal assemblages in each treatment were sampled using two $0.3 \times 0.3 \mathrm{~m}$ sub-quadrats placed in the centre of the plot (fixed position, marked with a screw; randomized positioning was not possible without introducing inconsistencies in substratum complexity). Abundances of macroalgae, sessile and mobile macroinvertebrates in experimental plots were sampled 4 days before the manipulation (half of the plots were sampled on 1 day, half the following day due to logistical constraints, 19-20.6.2006) and $7,21,36,69$ and 272 days thereafter. Data from sub-quadrats were averaged to give one value per plot $(\mathrm{N}=5$ per treatment) to avoid pseudoreplication.

\section{Data analysis}

Multivariate analyses on species abundance and cover data (analysed separately) were used to compare (1) assemblages across sites (>95\% Ascophyllum cover quadrats) at Hannafore Point (experiment site), Looe and Batten Bay; and (2) assemblages among experimental treatments at Hannafore Point. Differences between groups were visualized with nMDS based on BrayCurtis similarities and ANOSIM identified the relative range of dissimilarities between groups (Bonferroni correction was applied; Quinn \& Keough, 2002). SIMPER was applied to identify which taxa contributed most to the patterns identified in the ANOSIM and nMDS (contributions $>10 \%$ are reported). All multivariate statistics were performed using Primer v7.

Univariate analyses comparing abundances of individual taxa in quadrats with naturally $<95 \%$ canopy-cover of Ascophyllum between sites involved a single-factor ANOVA (Quinn \& Keough, 2002) with Site as a random factor (Hannafore Point, Looe and Batten Bay). To determine which taxa and abiotic factors were affected by an experimental reduction of Ascophyllum fronds, differences among experimental treatments were analysed using a single-factor repeated-measures ANOVA (hereafter rmANOVA) (Quinn \& Keough, 2002) with Treatment as a fixed factor. Response variables included species/taxon richness, individual species abundances, light and temperature. Where treatment $\times$ time interactions were significant, a one-way ANOVA and Tukey's test was undertaken for each sampling date to explain the differences between canopy controls and treatments (Quinn \& Keough, 2002). All univariate tests were performed using SYSTAT v13.

Probability distribution plots were examined to visually test for normality of data, and residual plots were examined for homogeneity of variance (Quinn \& Keough, 2002). Invertebrate count data were $\log (x+1)$ transformed to better meet these assumptions. Algal covers were untransformed because, while they were proportions, the inclusion of primary and secondary cover mean that total cover was not limited to $100 \%$, so the data did not follow a binomial distribution, for which a transformation would normally be used. As a check, analyses were done using arcsine-transformed data, and conclusions were identical. Untransformed data are presented here, because results are more easily interpretable. Where sphericity was not met in repeated-measures ANOVA, the Greenhouse-Geisser adjusted $P$-values were used (Quinn \& Keough, 2002).

\section{RESULTS}

\section{Spatial variation in assemblages associated with Ascophyllum nodosum}

The assemblages of mobile invertebrates (ANOSIM, Global $R=0.155, P=0.001)$ and sessile invertebrates and algae (Global $R=0.463, P=0.001)$ differed amongst sites and all three sites were distinct $(P=0.001$ for all pairwise comparisons). However, while statistically significant, the differences in the mobile invertebrate assemblages among sites were only slight (indicated by Global $R$ and pairwise $R$-values $<0.2$ ). The periwinkles Littorina littorea and Littorina obtusata, and the topshell Phorcus lineatus differed amongst sites (ANOVA, respectively: $F_{2,87}=15.991, P<0.001 ; F_{2,87}=$ 5.469, $\left.P=0.006 ; F_{2,87}=11.310, P<0.001\right)$. Littorina littorea accounted for $19-23 \%$ of the variation in mobile invertebrate assemblages among sites (mean \pm SEM: $1.94 \pm$ 0.12, $14.4 \pm$ $0.35,11.1 \pm 0.40$ per $\mathrm{m}^{2}$ at each of Hannafore Point, Looe and Batten Bay, respectively; SIMPER). Littorina obtusata accounted for $18-19 \%$ of the variation in mobile invertebrate assemblages among sites (mean \pm SEM: $13.3 \pm 0.30,13.7 \pm$ $0.28,7.8 \pm 0.21$ per $\mathrm{m}^{2}$ at each of Hannafore Point, Looe and Batten Bay, respectively; SIMPER). Phorcus lineatus accounted for $11-12 \%$ of the variation in mobile invertebrate assemblages when comparing Hannafore Point and Looe with Batten Bay (mean \pm SEM: $0.56 \pm 0.12,0.78 \pm 0.10,5.9 \pm$ 0.25 per $\mathrm{m}^{2}$ at each of Hannafore Point, Looe and Batten Bay, respectively; SIMPER). Variability in the abundances of Patella spp., Gibbula cinerera and Actinia equina accounted for a further $13-19 \%$ of the variation in mobile invertebrate assemblages (SIMPER) but there were no differences in their mean abundances among sites (ANOVA, respectively: $F_{2,87}=0.329$, $\left.P=0.720 ; F_{2,87}=0.841, P=0.435 ; F_{2,87}=0.602, P=0.550\right)$.

The differences in sessile invertebrate and algal assemblages among sites were stronger than those for mobile 
Table 1. Repeated measures ANOVA comparing changes following disturbance to Ascophyllum canopy at Hannafore Point for time, treatment and time $\times$ treatment, $\mathrm{N}=5$. All $\mathrm{df}$ are: Treatment $=3(16)$, Time $=4$, Treatment $\times$ Time $=12(64)$. $\mathrm{MS}_{\text {Residual }}$ and degrees of freedom are provided to allow reconstruction of the full ANOVA table.

\begin{tabular}{|c|c|c|c|c|c|}
\hline \multirow[t]{2}{*}{ Variable } & \multicolumn{2}{|l|}{ MS $_{\text {Residual }}$} & \multicolumn{3}{|l|}{ Effect } \\
\hline & Treatment & Time & Time $\times$ Treat & Treatment & Time \\
\hline Ascophyllum canopy cover & 958.0 & 74.8 & 0.011 & $<0.0005$ & $<0.0005$ \\
\hline Number of invertebrate species & 1.23 & 0.72 & 0.750 & $0.002^{\mathrm{a}}$ & 0.008 \\
\hline Littorina obtusata & 10.00 & 4.19 & 0.189 & $<0.0005^{\mathrm{a}}$ & 0.234 \\
\hline Littorina littorea & 0.31 & 0.08 & 0.550 & 0.442 & $<0.0005$ \\
\hline Phorcus lineatus & 0.04 & 0.10 & $0.003^{\mathrm{a}}$ & $<0.0005$ & $<0.0005$ \\
\hline Gibbula umbilicalis & 0.24 & 0.16 & $0.010^{* a}$ & 0.021 & $0.001^{*}$ \\
\hline Encrusting coralline algae & 406.6 & 140.7 & 0.844 & 0.073 & 0.032 \\
\hline Osmundea pinnatifida & 139.1 & 37.9 & $0.065^{*}$ & 0.222 & $<0.0005$ \\
\hline Fucus serratus & 799.7 & 199.7 & $0.003^{a}$ & 0.191 & $<0.0005$ \\
\hline Ulva spp. & 36.1 & 25.5 & $0.001^{* a}$ & 0.003 & $<0.0005^{*}$ \\
\hline Temperature $\left({ }^{\circ} \mathrm{C}\right)$ & 2.74 & 3.18 & 0.169 & $0.0001^{*}$ & $0.0001^{*}$ \\
\hline $\operatorname{PAR}\left(\mu \mathrm{mol} \mathrm{m} \mathrm{m}^{-2} \mathrm{~s}^{-1}\right)$ & $75,555.481$ & $37,660.959$ & $0.311 ; \mathrm{df}=6$ & o.002*; $\mathrm{df}=3$ & $0.252 ; \mathrm{df}=2$ \\
\hline
\end{tabular}

Statistical significance is indicated in bold, * indicates $P$-values adjusted to Greenhouse-Geisser Epsilon.

andicates significant Tukey's test (pairwise details described in Results text). Invertebrate count data were log $(x+1)$ transformed to meet assumptions of normality where necessary.

invertebrates (indicated by Global $R$ and pairwise $R$-values between $0.3-0.6$ for sessile species). Univariate analyses confirmed differences in the abundances of these species among sites, with Hannafore Point having the highest cover of Spirorbis spirorbis (ANOVA: $F_{2,87}=17.3, P<0.001$, mean $2.7 \% \pm 0.75$ ) compared with Looe (mean $2 \% \pm 0.70$ ) and Batten Bay (mean 0.5\% \pm 0.30). Osmundea pinnatifida, encrusting coralline algae and bare rock were less abundant at Hannafore Point (mean $0.1 \% \pm 0.12,<0.1 \% \pm 0.03$ and $<0.25 \% \pm 0.12$, respectively) compared with both Looe (mean $2.7 \% \pm 0.39,4.8 \% \pm 0.42$ and $2.8 \% \pm 0.45$, respectively) and Batten Bay (mean 1.3\% $\pm 0.37,3.8 \% \pm 0.46$ and $2.3 \% \pm 0.53$, respectively: ANOVA; $F_{2,87}=16.4, P<$ $0.001)$. Other sessile taxa accounted for less than $10 \%$ of the cumulative variation among sites (SIMPER) and were not investigated further.

\section{Effects of a pulse disturbance reducing densities of Ascophyllum fronds on the physical environment and associated assemblages}

\section{EFFECTS ON PHYSICAL ENVIRONMENT:}

TEMPERATURE AND LIGHT

Temperatures recorded in the $50 \%$ intact-frond treatment did not differ from those found in control $100 \%$ intact-frond plots (mean $20^{\circ} \mathrm{C} \pm 0.7$ and $19^{\circ} \mathrm{C} \pm 0.5$, respectively, Table $1: P>$ 0.05 , Figure 1 ). The $25 \%$ intact-frond treatment had increased mean temperatures, at least $1^{\circ} \mathrm{C}$ above that recorded in the $100 \%$ intact-frond control (Table 1: $P<0.05$, Figure 1). The 0 and $25 \%$ intact-frond treatments did not differ from each other with respect to temperature $(P>0.05)$ but both had increased mean temperatures, at least $1^{\circ} \mathrm{C}$ above that recorded in the $100 \%$ intact-frond control. The differences in average temperatures among treatments appear of a smaller magnitude in autumn and winter, but this was not supported statistically (time $\times$ treatment term, Table 1 , Figure 1 ). The variation in temperatures among treatments was consistent over time with the maximum daily temperatures recorded in plots over a 3-week period (maximum, minimum and average temperatures are illustrated in Appendix C; no analysis possible due to low replication). Maximum daily temperatures recorded over this same period were lowest in 50 and $100 \%$ intact-frond treatments, and highest in both the 0 and $25 \%$ intact-frond treatments (Appendix C).

Available light (as PAR) in plots only increased after complete frond removal (o\% intact fronds) when compared with the $100 \%$ intact-fronds control (Table 1, Figure 2). A trend towards increased light in the $25 \%$ intact-fronds treatment (Figure 2) relative to $100 \%$ intact-fronds control was evident when examining the means, but was not statistically significant $(P>0.05)$. Consistent with the patterns of variability in temperature among treatments, there was greater variability in available light amongst low frond-density treatments ( $\mathrm{o}$ and $25 \%$ intact fronds) compared with higher frond-density treatments (50 and $100 \%$ intact fronds) that had consistently low light levels (Figure 2).

\section{EFFECTS OF ASSOCIATED ASSEMBLAGES: MOBILE AND SESSILE MACROINVERTEBRATES AND MACROALGAE}

Manipulation of the density of Ascophyllum fronds resulted in variable levels of canopy cover at low tide over time and the degree of disturbance to the fronds did not directly correspond with percentage cover (Table 1, Figure 3). The 50 and 100\% intact-fronds treatments had similar Ascophyllum cover throughout the experiment (Table 1, Figure 3). From 7 to 36 days post-thinning, the $50 \%$ and $100 \%$ intact-fronds treatments had an average $85 \%$ Ascophyllum cover (Figure 3). Sixty-nine days post-thinning Ascophyllum declined to an average $77 \%$ cover in both treatments. The $25 \%$ intact-fronds treatment had lower Ascophyllum cover than both the 50\% and 100\% intact-fronds treatments, except at day 272 when a decline of Ascophyllum in the control and 50\% intact-fronds treatment resulted in similar percentage cover (Table 1, Figure 3). The $25 \%$ intact-fronds treatment had much higher (mean $\sim 60 \%$ throughout) Ascophyllum cover than the $0 \%$ intact-fronds treatment which had the lowest Ascophyllum cover (o\%) of all treatments (Table 1, Figure 3). 


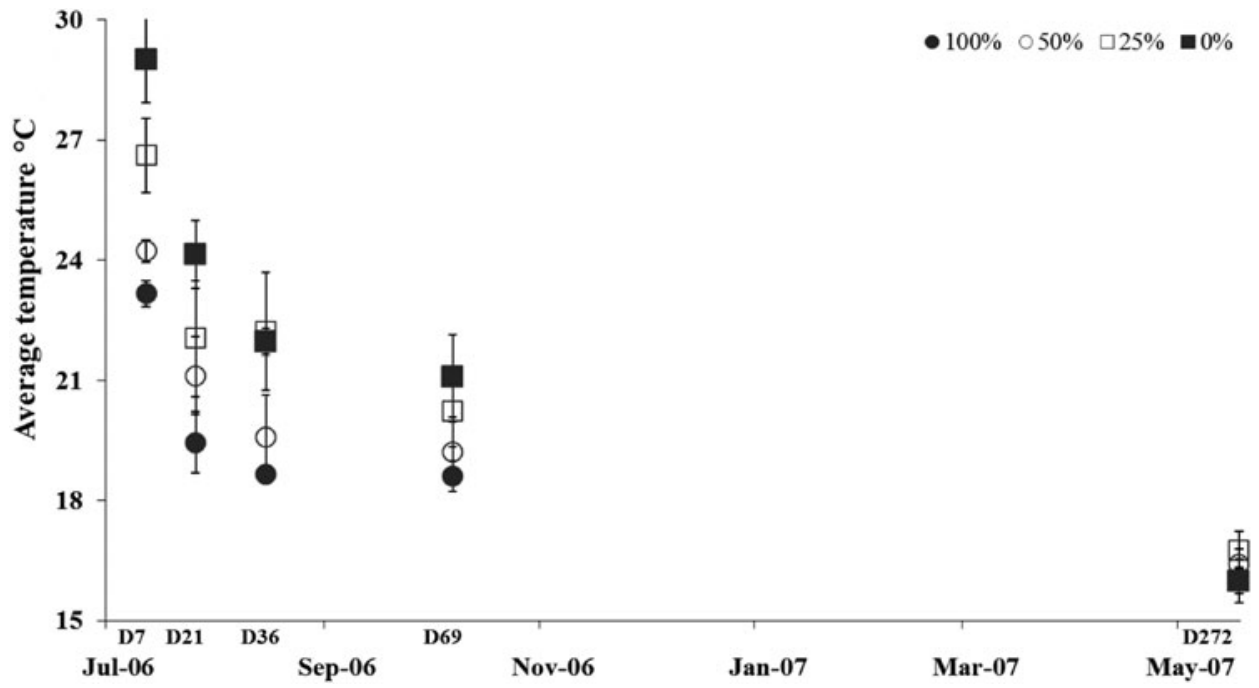

Fig. 1. Average temperature $\pm \mathrm{SE}$ recorded on substratum beneath canopy layer (where present) within plots through time, $\mathrm{N}=5 .{ }^{100} \%$ intact-fronds, $\bigcirc 50 \%$ intact-fronds, $\square 25 \%$ intact-fronds, $\square$ \% intact-fronds.

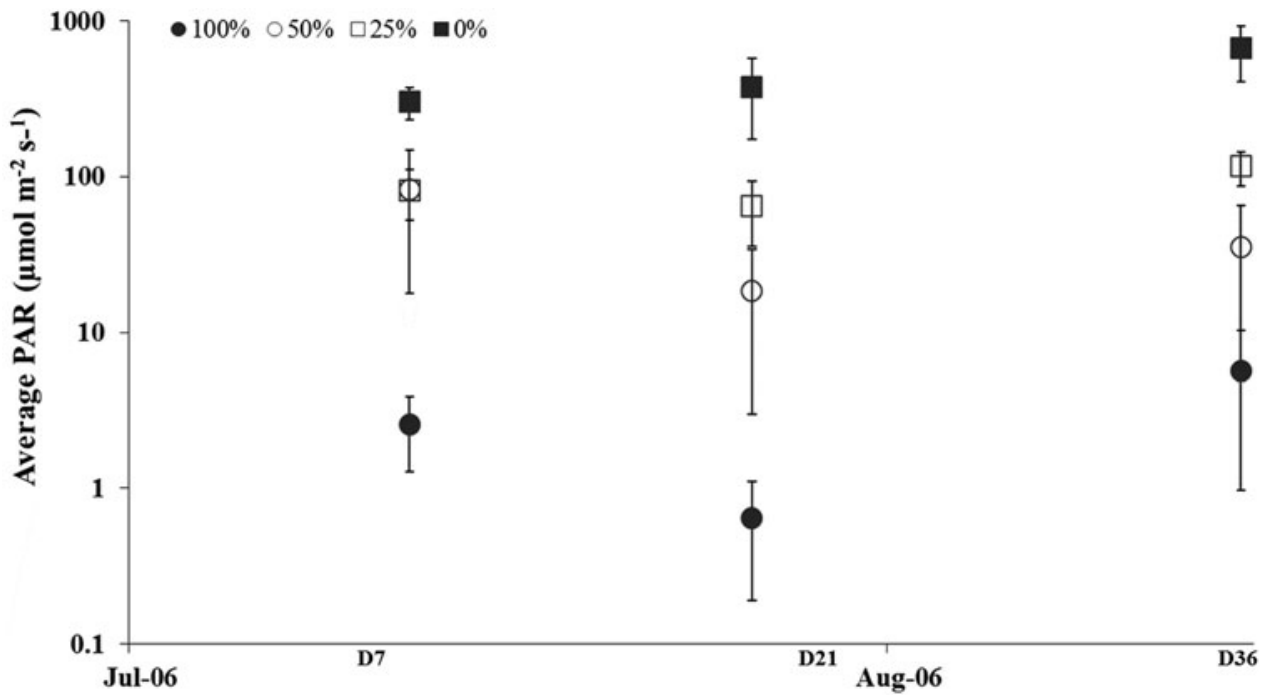

Fig. 2. Average photosynthetically active radiation $(\mathrm{PAR}) \pm \mathrm{SE}$ recorded on substratum beneath canopy layer (where present) within plots through time, $\mathrm{N}=5$. $100 \%$ intact-fronds, $\bigcirc 50 \%$ intact-fronds, $\square 25 \%$ intact-fronds, $\square$ o\% intact-fronds.

The assemblages of mobile and sessile taxa found in all plots were similar prior to experimental reductions of Ascophyllum (ANOSIM; Global $R<0, P>0.6$ ). Between 21 and 69 days after manipulation, assemblages of mobile or sessile taxa in the $50 \%$ intact-fronds treatment did not differ from those in the $100 \%$ intact-fronds control (Tables $2 \& 3$, Appendices A, B, D \& E). Up to 70 days post-removal, the $25 \%$ and $0 \%$ intact-fronds treatments had different assemblages of mobile and sessile taxa compared with controls (Tables 2 \& 3, Appendices A, B, D \& E). On the final sampling visit (Day 272, $\sim 9$ months after the pulse disturbance, 16 April 2007, spring) the mobile invertebrate species assemblages were not different among treatments (Table 3). This reflected partial recovery of Ascophyllum in the o\% intactfronds treatments (to $\sim 25 \%$ canopy cover, Figure 3 ), and an increase in the percentage cover of the mid-canopy species Fucus serratus across all plots $(\sim 50 \%$ canopy cover, Figure $5 \mathrm{C}$ ). There were, however, still significant differences after 9 months in the assemblages of sessile taxa in the $0 \%$ intact-fronds treatment compared with both the $25 \%$ and $100 \%$ intact-fronds treatments but the assemblages of sessile taxa in the $50 \%$ intact-fronds treatment did not differ from any other treatments (Appendix A).

All of the 10 mobile invertebrate species recorded (for full list see Appendix D) were found to contribute to differences identified in the ANOSIM analysis between the treatment types, although average abundances among treatment types and at different visits varied (further explained by univariate analyses below). Of all the sessile taxa (and/or cover components) sampled, Fucus serratus, encrusting corallines, bare rock, Spirorbis spirorbis, Osmundea pinnatifida, sand-covered rock, Mastocarpus stellatus, Ulva spp., Cladophora rupestris, Lomentaria articulata, unidentified red turf and the barnacle Perforatus perforatus, were found to contribute to the differences identified between canopy treatments (SIMPER). These individual species and habitat types were analysed 


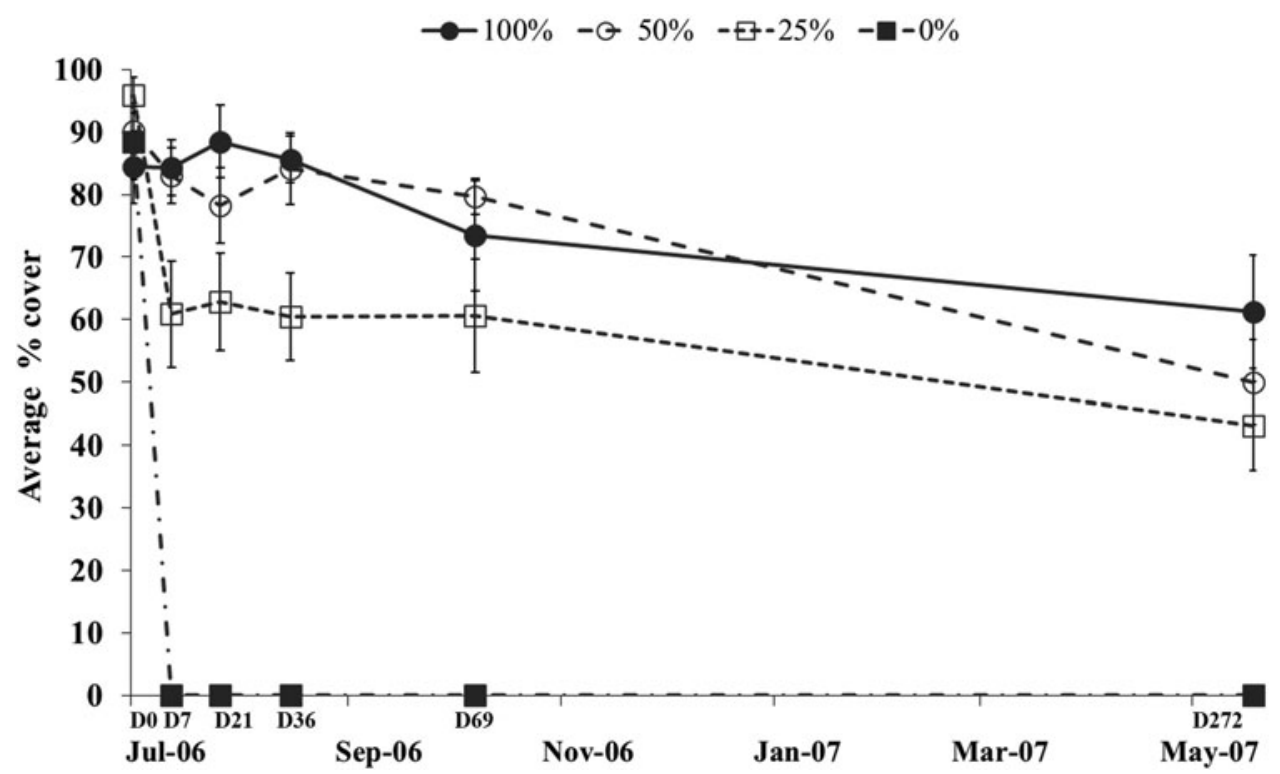

Fig. 3. Average percentage cover $\pm \mathrm{SE}$ of Ascophyllum canopy through time (not including holdfast fronds $<10 \mathrm{~cm}$ ), $\mathrm{N}=5$. intact-fronds, $\square 25 \%$ intact-fronds, $\square$ o\% intact-fronds.

Table 2. Pairwise ANOSIM comparing assemblages of sessile taxa (as percentage cover) among treatments (average for 2 subplots in each treatment area) at each sampling date, $\mathrm{N}=5$. Statistical significance (indicated by ${ }^{*}$ ) adjustment of alpha (Bonferonni correction) to o.oo8, relative difference using $R$ is indicated in bold.

\begin{tabular}{|c|c|c|c|c|c|c|c|c|c|c|}
\hline \multirow[t]{2}{*}{ Treatments } & \multicolumn{2}{|l|}{ Day 7} & \multicolumn{2}{|l|}{ Day 21} & \multicolumn{2}{|l|}{ Day 36} & \multicolumn{2}{|l|}{ Day 69} & \multicolumn{2}{|l|}{ Day 272} \\
\hline & $R$ & $P$ & $\boldsymbol{R}$ & $P$ & $R$ & $P$ & $R$ & $P$ & $R$ & $P$ \\
\hline Control, $\mathrm{F}_{50}$ & 0.332 & 0.024 & 0 & 0.460 & 0.036 & 0.373 & 0.228 & 0.079 & 0.128 & 0.159 \\
\hline Control, F25 & 0.316 & 0.048 & 0.096 & 0.239 & 0.196 & 0.063 & 0.064 & 0.31 & 0.176 & 0.135 \\
\hline Control, Fo & 0.556 & 0.016 & 0.396 & 0.024 & 0.340 & 0.024 & 0.904 & $0.008^{*}$ & 0.7 & $0.008^{*}$ \\
\hline $\mathrm{F}_{50}, \mathrm{~F}_{25}$ & 0.012 & 0.429 & -0.228 & 0.960 & -0.012 & 0.476 & -0.016 & 0.524 & -0.048 & 0.508 \\
\hline$F_{50}, F_{0}$ & 0.092 & 0.246 & 0.052 & 0.286 & 0.052 & 0.333 & 0.636 & $0.008^{*}$ & 0.24 & 0.063 \\
\hline $\mathrm{F} 25$, Fo & 0.492 & 0.016 & 0.26 & 0.079 & 0.20 & 0.175 & 0.504 & 0.016 & 0.388 & 0.024 \\
\hline GLOBAL R & 0.271 & 0.001 & 0.1 & 0.132 & 0.131 & 0.066 & 0.403 & 0.001 & 0.252 & 0.004 \\
\hline
\end{tabular}

Table 3. Pairwise ANOSIM comparing assemblages of mobile invertebrate species (invertebrate assemblage) among treatments (average for 2 subplots in each treatment area) at each sampling date, $\mathrm{N}=5$. Statistical significance (indicated by*) adjustment of alpha (Bonferonni correction) to o.oo8, relative difference using $R$ is indicated in bold.

\begin{tabular}{|c|c|c|c|c|c|c|c|c|c|c|}
\hline \multirow[t]{2}{*}{ Treatments } & \multicolumn{2}{|l|}{ Day 7} & \multicolumn{2}{|l|}{ Day 21} & \multicolumn{2}{|l|}{ Day 36} & \multicolumn{2}{|c|}{ Day 69} & \multicolumn{2}{|l|}{ Day 272} \\
\hline & $R$ & $P$ & $R$ & $P$ & $R$ & $P$ & $R$ & $P$ & $R$ & $P$ \\
\hline Control, $\mathrm{F}_{50}$ & -0.056 & 0.611 & -0.072 & 0.651 & -0.048 & 0.635 & 0.04 & 0.357 & -0.104 & 0.254 \\
\hline Control, F25 & 0.34 & $0.008^{*}$ & 0.312 & 0.024 & 0.608 & $0.008^{*}$ & 0.636 & $0.008^{*}$ & -0.06 & 0.635 \\
\hline Control, Fo & 0.628 & $0.008^{*}$ & 0.648 & $0.008^{*}$ & 0.368 & 0.032 & 0.656 & $0.008^{*}$ & 0.164 & 0.183 \\
\hline $\mathrm{F}_{50}, \mathrm{~F}_{25}$ & 0.184 & 0.063 & 0.264 & 0.056 & 0.452 & 0.016 & 0.488 & 0.024 & 0.004 & 0.460 \\
\hline $\mathrm{F}_{50}, \mathrm{Fo}_{0}$ & 0.656 & $0.008^{*}$ & 0.708 & $0.008^{*}$ & 0.24 & 0.071 & 0.472 & $0.008^{*}$ & 0.268 & 0.079 \\
\hline $\mathrm{F}_{25}$, Fo & -0.004 & 0.556 & 0.396 & 0.016 & -0.06 & 0.659 & 0.396 & 0.016 & 0.104 & 0.254 \\
\hline GLOBAL R & 0.294 & 0.005 & 0.369 & 0.001 & 0.256 & 0.007 & 0.442 & 0.001 & 0.066 & 0.177 \\
\hline
\end{tabular}

using univariate techniques (when they occurred in sufficient abundances) to further identify responses to reduction of Ascophyllum (Table 1, Figures 4 \& 5).

Invertebrate species richness in the $50 \%$ and $100 \%$ intactfronds treatments were similar on days 7 and 21 , with higher average species richness than both the $25 \%$ and $0 \%$ intact-fronds treatments (Table 1, Figure 4A, Tukey's $P<$ 0.05 ). On day 36 only the $50 \%$ intact-fronds treatment differed from other treatments, with higher species richness (Table 1 , Figure $4 \mathrm{~A}$, Tukey's $P<0.05)$. On day 69 , the $100 \%, 50 \%$ and $25 \%$ intact-fronds treatments had similar average species richness, all higher than the $0 \%$ intact-fronds 

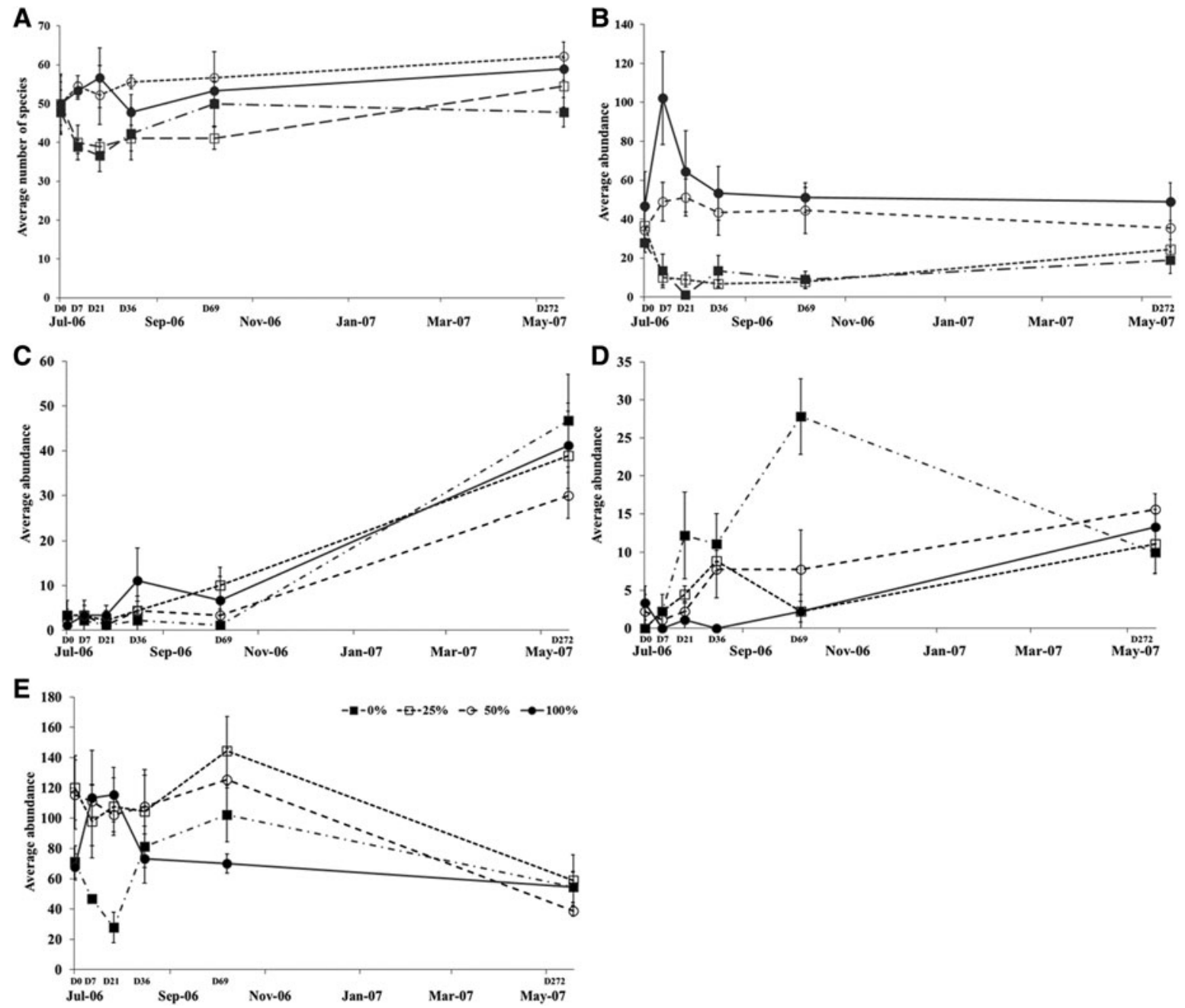

Fig. 4. Average abundances of invertebrates \pm SE found in treatment plots through time (per $\left.\mathrm{m}^{2}\right), \mathrm{N}=5$ : (A) species richness; (B) Littorina obtusata; (C) Littorina littorea; (D) Phorcus lineatus; (E) Gibbula umbilicalis. $100 \%$ intact-fronds, $\bigcirc 50 \%$ intact-fronds, $\square 25 \%$ intact-fronds, $\square 0 \%$ intact-fronds.

treatment (Table 1, Figure 4A, Tukey's $P<0.05$ ). At the end of the experiment, the $0 \%$ intact-fronds treatment had lower species richness than the $50 \%$ and $100 \%$ intact-fronds treatments (Table 1, Figure $4 \mathrm{~A}$, Tukey's $P<0.05$ ), but did not differ from the $25 \%$ intact-fronds treatment. The $25 \%$ intactfronds treatment had similar species richness to the $50 \%$ intact-fronds treatment, but remained lower than the $100 \%$ intact-frond control (Table 1, Figure 4A, Tukey's $P<0.05$ ).

Species-specific responses to disturbance

The abundance of the periwinkle Littorina obtusata differed among treatments throughout the study (Table 1, Figure 4B). On day 7 the $25 \%$ and $0 \%$ intact-fronds treatments had less than half the abundance $\left(\sim 1 / 0.09 \mathrm{~m}^{2}\right.$ compared with $\sim 4 / 0.09 \mathrm{~m}^{2}$ ) of L. obtusata found in the $50 \%$ intact treatments and less than a quarter of that found in the $100 \%$ intact-fronds control $\left(\sim 10 / 0.09 \mathrm{~m}^{2}\right.$, Figure $4 \mathrm{~B}$, Tukey's $\left.P<0.05\right)$. On days 21 and 69 , the $50 \%$ and $100 \%$ intact-fronds treatments had similar abundances of L. obtusata, which were higher than those recorded in both the $0 \%$ and $25 \%$ intact-fronds treatments (Figure $4 \mathrm{~B}$, Tukey's $P<0.05$ ). The same pattern was evident on day 36 , although not statistically significant (Table 1, Figure 4B). Littorina obtusata was more commonly observed on the fronds and holdfasts of Ascophyllum than under the canopy on the rock surface. In contrast, the abundance of the congeneric, largely rock-surface-dwelling, Littorina littorea did not respond to frond reductions but varied over time (Table 1 , Figure $4 \mathrm{C}$ ). The top shell Phorcus lineatus differed in abundance among treatments at different times throughout the study (Table 1, Figure $4 \mathrm{D}$ ). The abundance of $P$. lineatus in the $0 \%$ intact-fronds treatment was higher than in the $100 \%$ intact-fronds control on days 21 and 36 and higher than that in all other treatments on day 69 (Figure ${ }_{4} \mathrm{D}$, Tukey's $P<0.05$ ). The abundance of the top shell Gibbula umbilicalis varied among treatments on different sampling visits (Table 1, Figure $4 \mathrm{E}$ ). On days 7 and 21 there were fewer G. umbilicalis in the $0 \%$ intact-fronds treatment compared with other treatments; although no differences were identified on other sampling visits (Table 1 , Figure $4 \mathrm{E}$, Tukey's $P<0.05$ ).

Encrusting coralline algae did not differ $(P=0.066)$ in cover among treatments, though varied temporally, with a decline occurring on days 69 and 272 in all treatments (Table 1, Figure 5A). Although not quantified, a decline of the integrity of the encrusting coralline algae was observed in the $0 \%$ intact-fronds treatment, with a loss of pigment and surface peeling. Similarly, the cover of the turf-forming alga Osmundea pinnatifida did not vary among treatments, but varied over time, increasing in abundance on day 272 in 
A

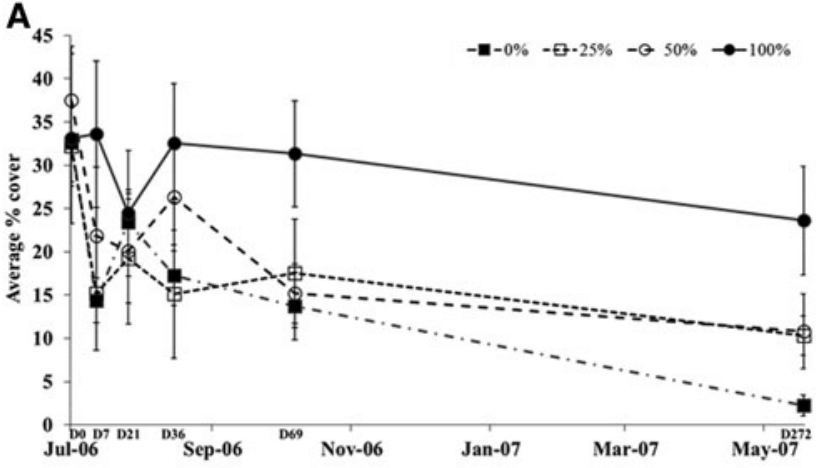

C

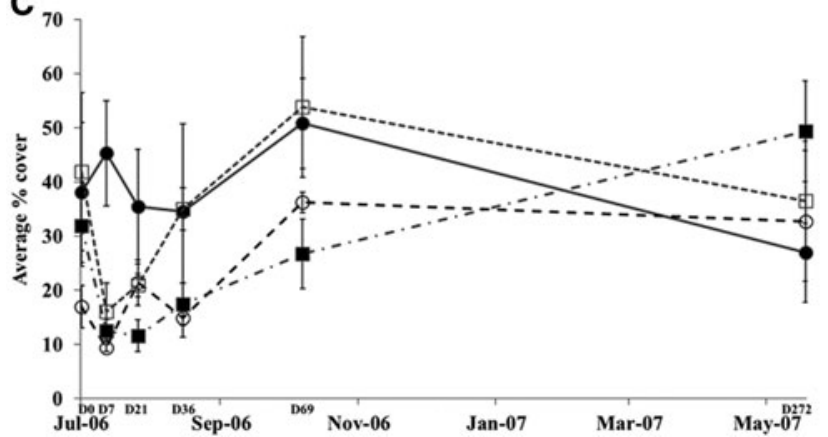

B
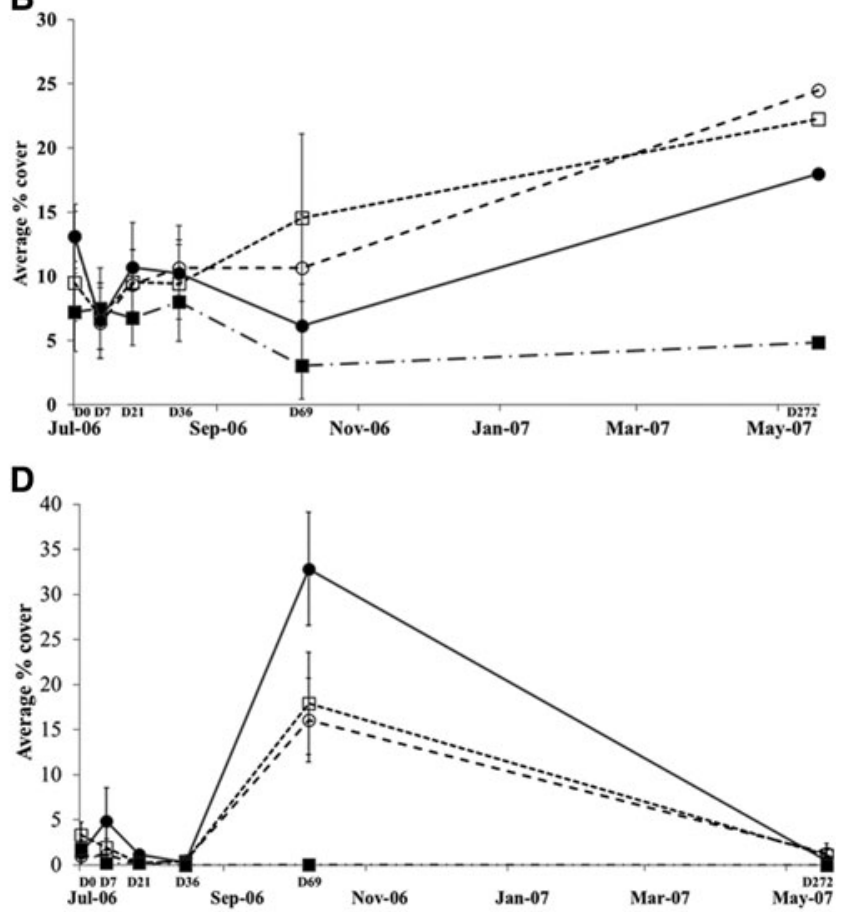

Fig. 5. Average percentage cover of associated algae \pm SE found in treatment plots through time, $\mathrm{N}=5$ : (A) encrusting coralline algae; (B) Osmondea pinnatifida; (C) Fucus serratus; (D) Ulva spp. $100 \%$ intact-fronds, $\bigcirc 50 \%$ intact-fronds, $\square 25 \%$ intact-fronds, $\square$ o intact-fronds.

the $100 \%, 50 \%$ and $25 \%$ intact-fronds treatments (Table 1 , Figure $5 \mathrm{~B}$ ). The differences in abundance of the fucoid alga, Fucus serratus, among treatments and the control were not consistent over time (Table 1, Figure $5 \mathrm{C}$ ). Fucus serratus had a higher percentage cover in the $100 \%$ intact-fronds control during day 7 compared with all other treatments; but no difference in percentage cover among treatments on other days (Table 1 , Figure ${ }_{5} \mathrm{C}$, Tukey's $P<0.05$ ). On day 272 a decline in abundance of $F$. serratus occurred in the control and $25 \%$ intact-fronds treatment and an increase occurred in the $0 \%$ intact-frond treatment (Table 1 , Figure ${ }_{5} \mathrm{C}$ ). The percentage cover of the algae Ulva spp. only differed among treatments and the control plots on day 69 (Table 1, Figure $5 \mathrm{D}$ ), with greater cover in the $100 \%$ intactfronds control (average 33\%) compared with the 50 and $25 \%$ intact-fronds treatments (both average $16 \%$, Tukey's $P$ $<0.05$ ), Ulva spp. were not recorded in the control plots. Ulva spp. remained below $5 \%$ cover throughout the rest of the study. Univariate analyses of additional taxa found during the study were not possible due to low abundances.

\section{DISCUSSION}

Theory predicts that the importance or role of a species as an ecosystem engineer will depend on interactions and thresholds between environmental stress and a suite of morphological and ecological traits (Jones et al., 1994, 1997; Bruno \& Bertness, 2001; Crain \& Bertness, 2006). Thus whilst a species may be considered to be an autogenic ecosystem engineer under one set of conditions (e.g. full canopy cover), it may cease to do so if these conditions break down. Intertidal rocky shores are particularly stressful environments with tidal cycles of emersion and gradients in physiological stress (e.g. desiccation, temperature, UV). Whilst full canopies of Ascophyllum have been demonstrated to act as autogenic ecosystem engineers and facilitate understorey biodiversity (Jenkins et al., 1999a, b, c, 2004; Jenkins \& Hawkins, 2003), we have demonstrated that this engineering role can be compromised by a pulse disturbance that reduces frond density and the ability of the canopy to modulate the physical environment. For Ascophyllum to act effectively as an autogenic ecosystem engineer at Hannafore Point, we found that at least $50 \%$ of the fronds (corresponding with $70-98 \%$ Ascophyllum cover) need to remain in order for temperature to remain cooler and for the associated invertebrate community to persist. With only $25 \%$ intact-fronds remaining (corresponding with 50-70\% Ascophyllum cover), macroalgae and sessile invertebrates could persist at Hannafore Point but at reduced abundances.

Ascophyllum altered the physical environment by reducing light and temperature within the understorey, but the effect varied amongst pulse disturbance treatments and was not proportional to frond densities. Ascophyllum reduced temperature in the $50 \%$ and $100 \%$ intact-fronds treatments. The maximum temperatures recorded using the continuous data loggers also suggest that the canopy may buffer from temperature extremes since the $50 \%$ and $100 \%$ intact-fronds treatments had the least variation in temperature. This more stable temperature is likely to exert less physical stress on species associating with the canopy and improve survival (Crisp, 1964). Ascophyllum also filtered light to the understorey in all plots except those in which fronds were completely removed (o\% intact-fronds treatment). Even the $25 \%$ intact-fronds treatment had an average light intensity six times lower than in the $0 \%$ intact-fronds treatment. Unexpectedly, percentage cover of Ascophyllum was not directly proportional to the density of fronds, and declined in 
all treatments with intact fronds over time. Throughout the experiment the percentage cover of Ascophyllum in the 50\% and $100 \%$ intact-fronds treatments were similarly high, suggesting that Ascophyllum can withstand high levels of frond breakage whilst still maintaining a high canopy percentage cover and its ecosystem engineering function. This pattern tracked an ongoing decline in canopy cover in $100 \%$ intactfrond controls, suggesting additional natural influences on canopy cover occurring at this site, which may influence ecosystem engineering function.

A marked short-term disturbance effect was observed 7 days after the treatments were applied with species assemblages varying between all treatments and the control. Changes in species assemblages related to stable temperatures in controls compared with increased temperatures in all treatments. Light intensity to the understorey increased as fronds were reduced, although the $50 \%$ and $25 \%$ intact-fronds treatments had similar light intensities, and the $0 \%$ intact-fronds treatment had the highest light intensity (more than double the highest recorded in the $25-50 \%$ treatments). This short-term response for all data suggests the assemblage needs somewhere between 7 and 21 days to recover from a single disturbance. This contrasts with the findings of Speidel et al. (2001) in Washington where abundances of littorinids, limpets and ephemeral algae did not differ among canopy reductions of Fucus gardneri despite rock temperatures being reduced by up to $7^{\circ} \mathrm{C}$ in all plots containing canopy algae. The differences in responses amongst these studies (Speidel et al., 2001 and this study) suggest that either particular species in Washington and the UK respond differently to canopy presence and/or rock temperature, or that rock temperature is not the driver of macroinvertebrate species patterns.

Our investigation found general similarities in responses of the community to those in Ascophyllum complete canopyremoval studies undertaken by Jenkins et al. on the Isle of Man (Jenkins et al., 1999a, b, c, 2004). In addition, we found that taxon richness was higher in the $100 \%$ and $50 \%$ intact-fronds treatments when compared with the $25 \%$ and $0 \%$ intact-fronds treatments. This pattern may also be related to differences in temperature amongst treatments. The algal turfs (e.g. Osmundea pinnatifida, Chondrus crispus) in the understorey of removed canopies on the Isle of Man (Jenkins et al., 1999b) were found to degrade once the canopy was lost. We also found this at Hannafore Point (Lomentaria sp. and Cladophora sp.), but the species differed. Ingólfsson \& Hawkins (2008) also found Cladophora sp. was lost following Ascophyllum removal in Iceland, and this loss persisted for 17 years despite canopy recovery. These studies in multiple locations suggest that a decline of turf-forming algae is a common response to Ascophyllum canopy loss and is likely a response to increased light and temperature when the canopy is removed (this study).

Although differences in abundance of Littorina obtusata occurred immediately after removal, subsequently abundances did not differ between the $50 \%$ and $100 \%$ intact-fronds treatments, but L. obtusata was much less common in the $25 \%$ and $0 \%$ intact-fronds treatments. Littorina obtusata occurs on the Ascophyllum canopy (Watson \& Norton, 1987; Williams, 1992) and even displays a facilitative relationship with its 'host', as its grazing of tissue causes the alga to produce phlorotannins, reducing its susceptibility to grazing by other invertebrates (Pavia \& Toth, 2000). Observations at all sites sampled in this study found a high number of $L$. obtusata attached to the fronds of Ascophyllum and since thinning and removal directly reduced fronds, this may explain lower abundances in the $25 \%$ and o\% intact-fronds treatments, especially at the beginning of the experiment.

Many of the taxa with reduced abundances in the $0 \%$ intact-fronds treatment were algae, suggesting that either higher light levels (Wiencke \& Davenport, 1988; see Kubler \& Raven, 1994; Irving et al., 2004), or increased herbivory by grazers such as Phorcus lineatus (Mieszkowska et al., 2007), impacted their survival in areas where the density of fronds was greatly reduced. De Figueiredo et al. (2000) reported that crustose corallines are common under algal canopies on rocky shores and in our study encrusting corallines bleached and peeled away from the surface in the o\% intactfronds treatment, suggesting they are sensitive to high light, drying, temperature exposure or a combination.

Disturbances that may result in thinning of Ascophyllum canopy include increased grazing intensity (species introductions or range shifts, Davies et al., 2007), climate change (reduced growth and recruitment) and trampling and harvesting (Boaden \& Dring, 1980; Keser et al., 2005; Araújo et al., 2009; Hawkins et al., 2009). Climate change is likely to affect Ascophyllum (Davies et al., 2007) and shore communities in a multitude of ways such as increased sea and air temperatures stressing its physiological processes (Svensson et al., 2009), increased storm activity causing physical damage, and the immigration and emigration of species that may compete or alter species interactions as local conditions change (e.g. increased grazer diversity and abundance, Hawkins et al., 2009). The only published studies to examine thinning of Ascophyllum canopies were undertaken in Portugal and examined press disturbances by human trampling (Araújo et al., 2009, 2012; Bertocci et al., 2011). Araújo et al. (2009) found trampling (at disturbance levels resulting in similar Ascophyllum cover to our $25 \%$ intact-fronds treatment) negatively impacted the community associated with Ascophyllum. Consistent with these studies (Araújo et al., 2009, 2012; Bertocci et al., 2011), we found a decreased abundance of some understorey species, but did not find increased Ulva spp. recruiting into $0 \%$ intact-fronds plots as seen in Portugal (Araújo et al., 2009). In contrast, Ulva spp. were in low abundance throughout the study at Hannafore Point with the exception of September 2006 (summer) where abundance spiked in all treatments except the $0 \%$ intact-fronds treatment. This is likely to be due to differences between sites and times of disturbance. Thinning of perennial intertidal fucoid algae was also investigated in New Zealand by Schiel \& Lilley (2007) on the Australasian species Hormosira banksii. Schiel \& Lilley (2007) found significant stepwise responses when comparing $0 \%, 25 \%$ and 50\% canopy cover treatments to the $75 \%$ canopy and unmanipulated control plots. This matches with our findings at Hannafore Point where the macroinvertebrate assemblages found in our $100 \%$ and $50 \%$ intact-fronds treatments (which correspond, in terms of Ascophyllum canopy cover, with their o\% reduction) differed from those found in the $25 \%$ and o\% intact-fronds treatments (which correspond, in terms of Ascophyllum canopy cover, with their $75 \%$ and $100 \%$ reductions). Given the similarities between our findings and other studies, management (e.g. restricted site access for sensitive locations) may be necessary to maintain the ecosystem engineering function of Ascophyllum, especially as frond breakage due to multiple climate change impacts (e.g. increased desiccation/grazing 
pressure/storms) is predicted to increase (Hawkins et al., 2009).

Despite the spatial variation in species assemblages from undisturbed canopies detected between our study sites, other thinning studies with spatially variable assemblages have shown similar general patterns within the understorey including the loss of sensitive algae (e.g. non-geniculate corallines, Lilley \& Schiel, 2006), a decline in species richness (Araújo et al., 2009) and replacement with other species (Jenkins et al., 1999c; Araújo et al., 2009).

The results of this study support the general findings of other studies investigating the consequence of Ascophyllum canopy disturbance to shore ecology (Jenkins et al., 1999a, b, c, 2004; Jenkins \& Hawkins, 2003; Ingólfsson \& Hawkins, 2008), but additionally demonstrate that there is a threshold of disturbance beyond which the autogenic engineering role of Ascophyllum is compromised. Reduction of more than $50 \%$ of fronds near the holdfast will reduce its ability to modulate temperature and light and to support the understorey community assemblage. Given that intact Ascophyllum canopies have been shown to support high levels of biodiversity elsewhere (Black \& Miller, 1991; Jenkins et al., 1999b, 2004; Keser et al., 2005; Davies et al., 2008; Ingólfsson \& Hawkins, 2008; Watt \& Scrosati, 2013), disturbance resulting in frond loss is likely to have widespread consequences, with slow recovery times when less than $50 \%$ of fronds remain intact. Our work demonstrates the value of investigating the conditions under which habitat-forming species may modulate the physical environment and act as autogenic ecosystem engineers to better manage the assemblages and biodiversity that they facilitate.

\section{SUPPLEMENTARY MATERIAL}

The supplementary material for this article can be found at https://doi.org/10.1017/So025315416002009

\section{ACKNDWLEDGEMENTS}

Thanks are given to several field assistants particularly Kate de la Haye and technical assistants from The Marine Biological Association of the United Kingdom. In kind support was provided by The Marine Biological Association of the United Kingdom. Feedback from two anonymous reviewers improved this manuscript.

\section{FINANCIAL SUPPDRT}

Funding was provided by the Ecological Society of Australia (student research award to J.B. Pocklington), Melbourne University (PORES and Drummond awards to J.B. Pocklington) and Museum Victoria (NHT grant to T.D. O'Hara). Additional funds were provided by The Marine Biological Association of the United Kingdom.

\section{REFERENCES}

Airoldi L. and Hawkins S.J. (2007) Negative effects of sediment depos ition on grazing activity and survival of the limpet Patella vulgata. Marine Ecology Progress Series 332, 235-240.
Ang P.O., Sharp G.J. and Semple R.E. (1996) Comparison of the structure of populations of Ascophyllum nodosum (Fucales, Phaeophyta) at sites with different harvesting histories. Hydrobiologia 327, 179-184.

Araújo R., Sousa-Pinto I., Serrão E. and Åberg P. (2012) Recovery after trampling disturbance in a canopy-forming seaweed population. Marine Biology 159, 697-707.

Araújo R., Vaselli S., Almeida M., Serrao E. and Sousa-Pinto I. (2009) Effects of disturbance on marginal populations: human trampling on Ascophyllum nodosum assemblages at its southern distribution limit. Marine Ecology Progress Series 378, 81-92.

Bellgrove A., Clayton M.N. and Quinn G.P. (1997) Effects of secondarily treated sewage effluent on intertidal macroalgal recruitment processes. Marine and Freshwater Research 48, 137-146.

Bertness M.D. and Leonard G.H. (1997) The role of positive interactions in communities: lessons from intertidal habitats. Ecology 78 , $1976-1989$.

Bertocci I., Araújo R., Vaselli S. and Sousa-Pinto I. (2011) Marginal populations under pressure: spatial and temporal heterogeneity of Ascophyllum nodosum and associated assemblages affected by human trampling in Portugal. Marine Ecology Progress Series 439, 73-82.

Black R. and Miller R. (1991) Use of the intertidal zone by fish in Nova Scotia. Environmental Biology of Fishes 31, 109-121.

Boaden P.J.S. and Dring M.T. (1980) A quantitative evaluation of the effects of Ascophyllum harvesting on the littoral ecosystem. Helgolander Meeresuntersuchungen 33, 700-710.

Bonsdorff E., Blomqvist E.M., Mattila J. and Norkko A. (1997) Coastal eutrophication: causes, consequences and perspectives in the Archipelago areas of the northern Baltic Sea. Estuarine, Coastal and Shelf Science 44(Suppl. 1), 63-72.

Bruno J. and Bertness M.D. (2001) Habitat modification and facilitation in benthic marine communities. In Bertness M.D., Gaines S.D. and Hay M.E. (eds) Marine community ecology. Sunderland, MA: Sinauer Associates, pp. 201-218.

Cervin G. and Åberg P. (1997) Do littorinids affect the survival of Ascophyllum nodosum germlings? Journal of Experimental Marine Biology and Ecology 218, 35-47.

Crain C.M. and Bertness M.D. (2006) Ecosystem engineering across environmental gradients: implications for conservation and management. Bioscience 56, 211-218.

Crisp D.J. (1964) The effects of the winter of $1962 / 63$ on the British marine fauna. Helgoland Marine Research 10, 313-327.

Davies A.J., Johnson M.P. and Maggs C.A. (2007) Limpet grazing and loss of Ascophyllum nodosum canopies on decadal time scales. Marine Ecology Progress Series 339, 131-141.

Davies A.J., Johnson M.P. and Maggs C.A. (2008) Subsidy by Ascophyllum nodosum increases growth rate and survivorship of Patella vulgata. Marine Ecology Progress Series 366, 43-48.

De O. Figueiredo M.A., Kain J.M. and Norton T.A. (2000) Responses of crustose corallines to epiphyte and canopy cover. Journal of Phycology $36,14-24$.

Gollety C., Thiébaut E. and Davoult D. (2011) Characteristics of the Ascophyllum nodosum stands and their associated diversity along the coast of Brittany, France. Journal of the Marine Biological Association of the United Kingdom 91, 569-577.

Hawkins S.J., Sugden H.E., Mieszkowska N., Moore P.J., Poloczanska E., Leaper R., Herbert R.J.H., Genner M.J., Moschella P.S., Thompson R.C., Jenkins S.R., Southward A.J. and Burrows M.T. (2009) Consequences of climate-driven biodiversity changes for 
ecosystem functioning of North European rocky shores. Marine Ecology Progress Series 396, 245-259.

Ingólfsson A. and Hawkins S.J. (2008) Slow recovery from disturbance: a 20 year study of Ascophyllum canopy clearances. Journal of the Marine Biological Association of the United Kingdom 88, 689-691.

Irving A.D., Connell S.D. and Elsdon T.S. (2004) Effects of kelp canopies on bleaching and photosynthetic activity of encrusting coralline algae. Journal of Experimental Marine Biology and Ecology 310, 1-12.

Jenkins S.R., Coleman R.A., Hawkins S.J., Burrows M.T. and Hartnoll R.G. (2005) Regional scale differences in determinism of grazing effects in the rocky intertidal. Marine Ecology Progress Series 287, 77-86.

Jenkins S.R. and Hawkins S.J. (2003) Barnacle larval supply to sheltered rocky shores: a limiting factor? Hydrobiologia 503, 143-151.

Jenkins S.R., Hawkins S.J. and Norton T.A. (1999a) Direct and indirect effects of a macroalgal canopy and limpet grazing in structuring a sheltered inter-tidal community. Marine Ecology Progress Series 188, $81-92$.

Jenkins S.R., Hawkins S.J. and Norton T.A. (1999b) Interaction between a fucoid canopy and limpet grazing in structuring a low shore intertidal community. Journal of Experimental Marine Biology and Ecology 233, 41-63.

Jenkins S.R., Norton T.A. and Hawkins S.J. (1999c) Interactions between canopy forming algae in the eulittoral zone of sheltered rocky shores on the Isle of Man. Journal of the Marine Biological Association of the United Kingdom 79, 341-349.

Jenkins S.R., Norton T.A. and Hawkins S.J. (2004) Long term effects of Ascophyllum nodosum canopy removal on mid shore community structure. Journal of the Marine Biological Association of the United Kingdom 84, 327-329.

Jenkins S.R., Moore P., Burrows M.T., Garbary D.J., Hawkins S.J. Ingólfsson A., Sebens K.P., Snelgrove P.V.R., Wethey D.S. and Woodin S.A. (2008) Comparative ecology of North Atlantic shores: do differences in players matter for process? Ecology 89, $\mathrm{S}_{3}-\mathrm{S}_{23}$.

Jones C.G., Lawton J.H. and Shachak M. (1994) Organisms as ecosystem engineers. Oikos 69, 373-386.

Jones C.G., Lawton J.H. and Shachak M. (1997) Positive and negative effects of organisms as physical ecosystem engineers. Ecology 78, $1946-1957$.

Keough M.J. and Quinn G.P. (1998) Effects of periodic disturbances from trampling on rocky intertidal algal beds. Ecological Applications $8,141-161$.

Keser M., Swenarton J.T. and Foertch J.F. (2005) Effects of thermal input and climate change on growth of Ascophyllum nodosum (Fucales, Phaeophyceae) in eastern Long Island Sound (USA). Journal of Sea Research 54, 211-220.

Kubler J.E. and Raven J.A. (1994) Consequences of light limitation for carbon acquisition in three rhodophytes. Marine Ecology Progress Series 110, 203-209.

Leonard G.H. (1999) Positive and negative effects of intertidal algal canopies on recruitment and survival of barnacles. Ecology 80, 1762-1769.

Lilley S.A. and Schiel D.R. (2006) Community effects following the deletion of a habitat-forming alga from rocky marine shores. Oecologia $148,672-681$

Littler M.M. and Murray S.N. (1974) The primary productivity of marine macrophytes from a rocky intertidal community. Marine Biology 27, $131-135$.

Menge B.A. and Olson A.M. (1990) Role of scale and environmental factors in regulation of community structure. Trends in Ecology and Evolution 5, 52-57.
Mieszkowska N., Hawkins S.J., Burrows M.T. and Kendall M.A. (2007) Long-term changes in the geographic distribution and population structures of Osilinus lineatus (Gastropoda: Trochidae) in Britain and Ireland. Journal of the Marine Biological Association of the United Kingdom 87, 537-545.

Pavia H. and Toth G.B. (2000) Inducible chemical resistance to herbivory in the brown seaweed Ascophyllum nodosum. Ecology 81, 3212-3225.

Petraitis P.S. and Dudgeon S.R. (1999) Experimental evidence for the origin of alternative communities on rocky intertidal shores. Oikos $84,239-245$.

Povey A. and Keough M.J. (1991) Effects of trampling on plant and animal populations on rocky shores. Oikos 61, 355-368.

Quinn G.P. and Keough M.J. (2002) Experimental design and data analysis for biologists, 1st edition. Cambridge: Cambridge University Press.

Rönnberg C. and Bonsdorff E. (2004) Baltic Sea eutrophication: areaspecific ecological consequences. In Kautsky H. and Snoeijs P. (eds) Biology of the Baltic Sea, Volume 176. Amsterdam: Springer, pp. 227-241.

Schiel D. and Lilley S. (2007) Gradients of disturbance to an algal canopy and the modification of an intertidal community. Marine Ecology Progress Series 339, 1- 11 .

Schiel D.R. and Taylor D.I. (1999) Effects of trampling on a rocky intertidal algal assemblage in southern New Zealand. Journal of Experimental Marine Biology and Ecology 235, 213-235.

Schiel D.R., Wood S.A., Dunmore R.A. and Taylor D.I. (2006) Sediment on rocky intertidal reefs: effects on early post-settlement stages of habitat-forming seaweeds. Journal of Experimental Marine Biology and Ecology 331, 158-172.

Speidel M., Harley C.D.G. and Wohnam M.J. (2001) Recovery of the brown alga Fucus gardneri following a range of removal intensities. Aquatic Botany 71, 273-280.

Stephenson T.A. and Stephenson A. (1972) Life between tidemarks on rocky shores. San Francisco, CA: W. H. Freeman and Company.

Svensson C., Pavia H. and Åberg P. (2009) Robustness in life history of the brown seaweed Ascophyllum nodosum (Fucales, Phaeophyceae) across large scales: effects of spatially and temporally induced variability on population growth. Marine Biology 156, 1139-1148.

Thompson R.C., Crowe T.P. and Hawkins S.J. (2002) Rocky intertidal communities: past environmental changes, present status and predictions for the next 25 years. Environmental Conservation 29, 168-191.

Ugarte R.A., Sharp G. and Moore B. (2006) Changes in the brown seaweed Ascophyllum nodosum (L.) Le Jol. Plant morphology and biomass produced by cutter rake harvests in southern New Brunswick, Canada. Journal of Applied Phycology 18, 351-359.

Underwood A.J. (1998) Grazing and disturbance: an experimental analysis of patchiness in recovery from a severe storm by the intertidal alga Hormosira banksii on rocky shores in New South Wales. Journal of Experimental Marine Biology and Ecology 231, 291-306.

Underwood A.J. (1999) Physical disturbances and their direct effect on an indirect effect: responses of an intertidal assemblage to a severe storm. Journal of Experimental Marine Biology and Ecology 232, 125-140.

Watson D.C. and Norton T.A. (1987) The habitat and feeding preferences of Littorina obtusata (L.) and L. mariae sacchi et rastelli. Journal of Experimental Marine Biology and Ecology 112, 61-72.

Watt C.A. and Scrosati R.A. (2013) Regional consistency of intertidal elevation as a mediator of seaweed canopy effects on benthic species richness, diversity and composition. Marine Ecology Progress Series 491, 91-99.

Wernberg T., Bennett S., Babcock R.C., de Bettignies T., Cure K., Depczynski M., Dufois F., Fromont J., Fulton C.J., Hovey R.K., 
Harvey E.S., Holmes T.H., Kendrick G.A., Radford B., Santana-Garcon J., Saunders B.J., Smale D.A., Thomsen M.S. Tuckett C.A., Tuya F., Vanderklift M.A. and Wilson S.K. (2016) Climate driven regime shift of a temperate marine ecosystem. Science 353, 169-172.

Wiencke C. and Davenport J. (1988) Respiration and photosynthesis in the intertidal alga Cladophora rupestris (L.) Kutz. under fluctuating salinity regimes. Journal of Experimental Marine Biology and Ecology $114,183-197$

Williams G.A. (1992) The effect of predation on the life histories of Littorina obtusata and Littorina mariae. Journal of the Marine Biological Association of the United Kingdom 72, 403-416. and

Zemke-White W.L. and Masao O. (1999) World seaweed utilisation: an end-of-century summary. Journal of Applied Phycology 11, 369-376.

\section{Correspondence should be addressed to:}

J. B. Pocklington

School of Marine Science and Technology, Newcastle University, Dove Marine Laboratory, Cullercoats, Tyne \& Wear NE30 4 PZ, UK

email: jpocklington@museum.vic.gov.au 